\title{
Platelet-rich plasma in muscle injuries: A possible kind of treatment in regenerative sport traumatology
}

\author{
Caforio Marco*, Mantelli Patrizia and Bisogno Luigi \\ Department of Orthopedic and Traumatology, Scarnati Clinic, Cosenza, Italy
}

\begin{abstract}
Muscle injuries are the most frequent cause to inability to sport exercises. The aim of any treatment is the return to the normal sport activity like before trauma. Many treatments have been purposed in the literature: recently the use of Platelet-Rich Plasma (PRP) has been described with good results. In this review all studies searched electronically using the PubMed database have been analyzed to discovery the validity, modality and efficiency of PRP injections in muscle injuries. In literature few studies are published and all of them demonstrate good results but timing, quantity, frequency and how use a PRP injection protocol remain important questions.
\end{abstract}

\section{Introduction}

Muscle injuries are one of the commonest types of injuries occurring in athletes. They are about $31 \%$ of all injuries in elite football (soccer) [1] and often these injuries results in loss of training and competition time. Thigh muscle injuries represent those most commonly diagnosed in track and field athletes (16\%) but have also been documented in team sports like rugby (10.4\%), basketball (17.7\%) and American football (46\%/22\% practice/games) [2]. A correct evaluation, diagnosis and therapy of the index muscle disorder is important for a correct choose of treatment: the therapeutic approach is based on the degree of injury [3].

In the simplest cases, in which the myofibrillar architecture is not involved, the treatment is mainly represented by RICE, non-steroidal anti-inflammatory drugs (NSAIDs) and physical therapy (with active and passive modalities). In more serious cases, where there is also a miotendinous side involvement, the treatment of choice is surgery. However, in all cases rarely reaches a restitution ad integrum of damaged tissue [4] and this is the reason that drove the search to experience with new application techniques of tissue biology [5]. Recently, autologous platelet-rich plasma (PRP) injection has gained a lot of attention in the treatment of sports injuries including muscle injury. The rationale of PRP use is the belief that the additional Growth Factors (GFs) released by platelets augment the natural healing process [6]. Despite its increasing popularity as a treatment for muscle injuries there is a growing debate regarding PRP clinical efficacy $[7,8]$.

Objective of this systematic review is to evaluate the evidence-based medicine about PRP infiltration in muscle injuries with a computerized literature search, with citation tracking and hand searching for original studies to assess the effect of this kind of treatment.

\section{Materials and methods}

All studies were searched electronically using the following PubMed database. Published systematic reviews about PRP injections were used as a source of randomized controlled trials. Peer-reviewed published articles until December 2012 were used; only articles published in English were considered. The titles and abstracts of all studies retrieved from the search were reviewed following criteria for study selection. The outcomes extracted from the selected study were not combined and re-analysed due to the nature of this qualitative systematic review. The Physiotherapy Evidence Database Scale (PEDro) for randomized controlled trials has been used: a PEDro score of $=6$ was considered to represent a high quality study, whereas a score of $=5$ represented a low quality study.

\section{Results}

The search identified 932 potential articles from the databases search but a lot of them were excluded because the studies were not on autologous PRP and muscle injury. Of the 22 full-text articles retrieved for further evaluation, only 4 articles were included in the final qualitative synthesis. The remaining 37 articles were excluded because 35 of these articles were review articles (including systematic reviews) and the remaining 2 were case reports.

Our research had found only one human study (Wright-Carpenter $\mathrm{T}$ et al. [9], published in 2004 on International Journal of Sport Medicine), a pilot controlled trial conducted considering professional sportsmen with moderate strains, and three animal / laboratory studies (another study of Wright-Carpenter T et al. [10], published in 2004 on International Journal of Sport Medicine; Hammon JW et al. [11], published in 2009 on American Journal of Sport Medicine; Gigante A et al. [12], published in 2012 on Journal of Biological Regulators and Homeostatic Agents) (Table 1).

${ }^{*}$ Correspondence to: Marco Caforio, MD, Department of Orthopedic and Traumatology, Scarnati Clinic, Cosenza, Via Zara, 87100, Cosenza, Italy, Fax: 390984837061; E-mail: dottorcaforio@gmail.com

Key words: PRP, muscle injuries, sport traumatology, biotechnologies

Received: June 27, 2018; Accepted: July 12, 2018; Published: July 16, 2018 
Table 1. Our research on the effects of PRP therapy after muscle injuries

\begin{tabular}{|c|c|c|c|c|}
\hline Object of study & Studies & Outcome measurements & Groups of study & Results \\
\hline $\begin{array}{l}\text { Professional sportsmen with a } \\
\text { moderate strains }\end{array}$ & $\begin{array}{l}\text { Wright-Carpenter T et al. (2004) Int } \\
\text { J Sports Med 25: 588-593 }\end{array}$ & $\begin{array}{l}\text { Mean recovery time to resume full } \\
\text { sporting activity and regression of } \\
\text { muscle edema and bleeding with } \\
\text { MRI }\end{array}$ & $\begin{array}{l}\text { PRP infiltration group compared to } \\
\text { no treatment }\end{array}$ & $\begin{array}{l}\text { A shorter mean recovery time and a } \\
\text { faster regression of edema/bleeding } \\
\text { in PRP infiltration group. }\end{array}$ \\
\hline \multirow{3}{*}{ Animal / Laboratory study } & $\begin{array}{l}\text { Wright-Carpenter T et al. (2004) Int } \\
\text { J Sports Med 25: 582-587 }\end{array}$ & $\begin{array}{l}\text { Speed and diameter of the } \\
\text { regenerated myofibers after one } \\
\text { week of mice gastrocnemius } \\
\text { muscles injuries }\end{array}$ & $\begin{array}{l}\text { PRP infiltrations compared to } \\
\text { Actovegin/Traumeel treatment }\end{array}$ & $\begin{array}{l}\text { A faster recovery of injured with } \\
\text { myofibers with a bigger diameter in } \\
\text { PRP infiltration group }\end{array}$ \\
\hline & $\begin{array}{l}\text { Hammond JW et al. (2009) Am J } \\
\text { Sports Med 37: 1135-1142 }\end{array}$ & $\begin{array}{l}\text { Residual contractile function after } \\
\text { rats tibialis anterior muscles injured }\end{array}$ & $\begin{array}{l}\text { PRP infiltration group, PPP } \\
\text { infiltration group as a sham } \\
\text { treatment, no treatment group }\end{array}$ & $\begin{array}{l}\text { A better contractile function in PRP } \\
\text { infiltration group }\end{array}$ \\
\hline & $\begin{array}{l}\text { Gigante A et al. (2012) J Biol Regul } \\
\text { Homeost Agents 26: } 475-484\end{array}$ & $\begin{array}{l}\text { Muscle regeneration with an } \\
\text { histological, immunohistochemical } \\
\text { and histomorphometric analyses } \\
\text { of rats longissimus-dorsi muscles } \\
\text { injuries }\end{array}$ & $\begin{array}{l}\text { PRFM infiltration group compared } \\
\text { to no treatment }\end{array}$ & $\begin{array}{l}\text { A better muscle regeneration, an } \\
\text { increase in neovascularization and a } \\
\text { slight reduction of fibrosis in PRFM } \\
\text { infiltration group }\end{array}$ \\
\hline
\end{tabular}

\section{Discussion}

There are many kinds of treatment to speed muscle healing: the combination of Traumeel S, Actovegin and local anaesthetic injection into injured muscle is very popular in Europe, despite the fact that there is no good clinical evidence of efficacy and little theoretical scientific basis [13]. About PRP, the GFs are provided in physiological proportions with the hope this will accelerate healing and lead to a balance of proliferative and inhibitory effects. Although this has theoretical and basic science underpinnings there has been little published quality research on the use of PRP in muscle: in fact in our research we have found a few study, expecially in human muscle. In only one study conducted in sportsmen [9] the diagnosis of injury was based with a magnetic resonance imaging (MRI). The PRP-infiltration protocol was intralesional injection of $2.5 \mathrm{ml}$ autologous conditioned serum (ACS), combined with $2.5 \mathrm{ml}$ of saline, through palpation of the affected area, started two days after diagnosis and repeated every second day until full recovery. The main outcome measured was the time required to resume full sporting activities and the return to full sporting activities. The mean recovery time for participants in the group of PRP infiltration (16.6 days) was significantly shorter compared to the control group (22.3 days). In addition, MRI scans taken at 16 days in both groups demonstrated faster regression of the edema/bleeding in the PRP infiltration group. The number of professional sportsmen are small (11) with a heterogeneous variety of muscle strains and there was no true 'control' group, as the 'control group' had been treated with Traumeel S and Actovegin, and was reviewed, retrospectively.

The first animal and laboratory studies appeared in 2000: the role of basic fibroblast growth factor (b-FGF), insulin growth factor type 1 (IGF-1) and nerve growth factor (NGF) like potent stimulators of the proliferation and fusion of myoblasts in vitro was observed in mice with lacerations of the gastrocnemius muscle (study published on Journal Bone and Joint Surgery by Menetrey et al. [14]). This study evaluated the effect of GFs on the proliferation and fusion of myoblasts in vitro and noting a stimulate cell migration and myofibroblastic differentiation. Then Wright-Carpenter in 2004 studied the effects of a local administration of GFs presented in ACS of a laboratory mice, after muscle contusion. The study group received local injections of ACS at 2 hours, 24 hours, and 48 hours after injury, and a control group received saline injections only. The histology results showed that satellite cell activation at 30/48 hours post injury was accelerated and the diameter of the regenerating myofibers was increased compared to the controls within the first week after injury. Then they concluded that this approach can reduce the time of recovery from muscle injury [10]. In 2009 Hammond and his collaborators demonstrated the efficacy of use of autologous PRP evaluated the effects of no treatment compared to a PRP injection or Platelet-Poor Plasma (PPP) injection treatment: they demonstrated a better recovery of contractile function in PRP injection group [11]: the difference between PRP and PPP infiltration is due to PRP is rich in GFs that can stimulate myogenesis. Gigante in 2012 [12] compared Platelet Rich Fibrin Matrix (PRFM), as a source of GFs, treatment to no treatment: The Authors performed lesions in longissimus-dorsi muscles of rats, in one of them PRFM was injected, the contralateral muscle was left untreated (control groups) and a more muscle regeneration and vascularization in PRFM group was demonstrated after histological, immunohistochemical and histomorphometric analyses. No differences were detected for inflammation, and metaplasia, ossification and heterotopic calcification cases were not detected. But serious questions remain as when and how to use PRP in muscle injury. A muscle is an actively healing, acutely inflammatory entity and potentially can adversely affect both the timing and the quality of repair. PRP is heterogeneous, and it may be that certain types of PRP are more effective than others. The timing, quantity and frequency of injections required are also in question.

\section{Conclusion}

There are limited studies on the effects of PRP therapy on recovery of function after muscle injuries. This review identified only a single pilot human controlled trial and three in vivo laboratory studies. The complete response to the use of PRP injection treatment in muscle injuries will be possible only when all studies can be performed on humans patients. Further studies of satisfactory methodological quality with PRP interventions on acute muscle injuries are needed to establish the effectiveness, indications and protocols.

\section{References}

1. Ekstrand J, Hägglund M, Waldén M (2011) Epidemiology of muscle injuries in professional football (soccer). Am J Sports Med 39: 1226-1232. [Crossref]

2. Mueller-Wohlfahrt HW, Haensel L, Mithoefer K, Ekstrand J, English B, et al. (2012) Terminology and Classification of Muscle Injuries in Sport: A Consensus Statement. $\mathrm{Br}$ J Sports Med 47: 342-350. [Crossref]

3. Ramos LA, de Carvalho RT, Abdalla RJ, Ingham SJ (2015) Surgical treatment for muscle injuries. Curr Rev Musculoskelet Med 8: 188-192. [Crossref]

4. Järvinen TA, Järvinen TL, Kääriäinen M, Kalimo H, Järvinen M (2005) Muscle injuries: biology and treatment. Am J Sports Med 33: 745-764. [Crossref]

5. Turner NJ, Badylak SF (2013) Biologic scaffolds for musculotendinous tissue repair. Eur Cell Mater 25: 130-143. [Crossref]

6. Moraes VY, Lenza M, Tamaoki MJ, Faloppa F, Belloti JC (2013) Platelet-rich therapies for musculoskeletal soft tissue injuries. Cochrane Database Syst Rev 12: CD010071. [Crossref] 
7. Mei-Dan O, Lippi G, Sánchez M, Andia I, Maffulli N (2010) Autologous platelet-rich plasma: a revolution in soft tissue sports injury management? Phys Sportsmed 38: 127135. [Crossref]

8. Schwarz AA (2009) Promising Treatment for Athletes, in Blood. The New York Times, New York, NY.

9. Wright-Carpenter T, Klein P, Schäferhoff P, Appell HJ, Mir LM, et al. (2004) Treatment of muscle injuries by local administration of autologous conditioned serum: a pilot study on sportsmen with muscle strains. Int J Sports Med 25: 588-593. [Crossref]

10. Wright-Carpenter T, Opolon P, Appell HJ, Meijer H, Wehling P, et al. (2004) Treatment of muscle injuries by local administration of autologous conditioned serum: anima experiments using a muscle contusion model. Int J Sports Med 25: 582-587. [Crossref]
11. Hammond JW, Hinton RY, Curl LA, Muriel JM, Lovering RM (2009) Use of autologous platelet-rich plasma to treat muscle strain injuries. Am J Sports Med 37: 1135-1142. [Crossref]

12. Gigante A, Del Torto M, Manzotti S, Cianforlini M, Busilacchi A, et al. (2012) Platelet rich fibrin matrix effects on skeletal muscle lesions: An experimental study. $J$ Biol Regul Homeost Agents 26: 475-484. [Crossref]

13. Orchard JW, Best TM, Mueller-Wohlfahrt HW, Hunter G, Hamilton BH, et al. (2008) The early management of muscle strains in the elite athlete: best practice in a world with a limited evidence basis. Br J Sports Med 42: 158-159. [Crossref]

14. Menetrey J, Kasemkijwattana C, Day CS, Bosch P, Vogt M, et al. (2000) Growth factors improve muscle healing in vivo. J Bone Joint Surg Br 82: 131-137. [Crossref]

Copyright: $\odot 2018$ Marco C. This is an open-access article distributed under the terms of the Creative Commons Attribution License, which permits unrestricted use, distribution, and reproduction in any medium, provided the original author and source are credited. 